\title{
SIMULASI NUMERIK PERBANDINGAN KARAKTERISTIK ALIRAN PADA PENAMBAHAN SPIRAL DI UJUNG NOZZLE Setyo Hariyadi S.P. ${ }^{1,2}$, Faidurrahim ${ }^{1}$ \\ 1) Laboratorium Mekanika dan Mesin Fluida
}

Jurusan Teknik Mesin, Fakultas Teknologi Industri, Institut Teknologi Sepuluh Nopember (ITS)

Jl. Arief Rahman Hakim, Surabaya 60111 Indonesia

2) Program Studi Teknik Pesawat Udara, Politeknik Penerbangan Surabaya

Jl. Jemur Andayani I/73, Wonocolo, Surabaya 60236

Email: hudzaifahsetyo@gmail.com

\begin{abstract}
Abstrak
Perkembangan industri yang semakin pesat salah satu efek sampingnya adalah semakin bertambahnya polusi udara. Permasalahan polusi udara ini memerlukan suatu sistem pengontrol debu. Beragam jenis nozzle yang digunakan dalam proses pengontrolan debu, salah satunya adalah spiral nozzle.

Spiral nozzle digolongkan pada jenis nozzle subsonic. Pola sebaran semprotan dilakukan dengan pemodelan numerik.. Pemodelan ini terdiri dari geometri nozzle beserta ruang semprotannya.

Hasil pemodelan dengan menggunakan perangkat lunak CFD (Computational Fluid Dynamics) diperoleh bahwa pembesaran sudut tip $(\alpha)$ spiral nozzle mempengaruhi kenaikan sudut semprotan $(\beta)$ dan panjang penetrasinya.. Besar kecilnya kenaikan akan dipengaruhi oleh beban tekanan dan debit yang diberikan. Pada akhir analisis diperoleh nozzle yang maksimal pada kondisi dan pembebanan tertentu.
\end{abstract}

Kata kunci : $C F D$, spiral nozzle, sudut tip nozzle, sudut semprotan, panjang penetrasi

\section{Industrial development will go further and one of negative effect is air pollution become} raised. The problems of air pollution need a system of dust control. Many type of nozzle being used in dust control process, one is spiral nozzle.

Spiral nozzle classified as subsonic nozzle. The pattern of spray will do by numerical model. This model consists of nozzle geometry with spray chamber.

The result solved by CFD (Computational Fluid Dynamics) that the increase of spray cone angle $(\alpha)$ at spiral nozzle tip will also increase spray angle $(\beta)$ and the penetration. The range of increment depends on load of pressure and volume flow rate. The final analysis, a maximum criteria of nozzle that applied in typical range of loading was choose.

Keyword : CFD, spiral nozzle, nozzle angle tip, spray angle, penetration distance

\section{PENDAHULUAN}

Perkembangan ilmu pengetahuan dan teknologi yang pesat mendorong manusia untuk semakin banyak melakukan penelitian di dalam berbagai hal yang bertujuan untuk mengetahui suatu konsep atau gejala agar penerapannya dalam aplikasi teknik bisa optimal. Seiiring dengan berkembangnya industri maka salah satu efek sampingnya adalah semakin bertambahnya jumlah polusi udara. Permasalahan untuk menanggulangi hal ini maka diperlukan pengontrolan debu hasil pembakaran atau proses lain yang menghasilkan partikel-partikel berbahaya bagi lingkungan dan manusia agar tidak ikut terbawa bersama udara. Salah satu usaha untuk menurunkan polusi udara adalah dengan membuat sistem dust collector. Sistem ini bekerja dengan cara yaitu partikel-partikel debu yang akan dibuang keluar akan disemprot dengan air yang tersebar melalui sebuah nozzle. Proses penyemprotan ini mengakibatkan partikel-partikel debu akan menumbuk partikel-partikel air sehingga akan membentuk suatu campuran partikel air dan debu yang akan jatuh ke bawah.

Partikel debu diharapkan dapat dikenai partikel air maka diperlukan nozzle dengan sebaran tertentu sesuai dengan sistem yang ada, sehingga dibutuhkan karakteristik nozzle yang 
mempengaruhi pola semprotannya. Salah satu jenis nozzle yang dipakai untuk sistem dust collector adalah spiral nozzle. Karena bentuk nozzle yang spesifik ini mendorong penulis untuk melakukan simulasi numerik terhadap proses atomisasi air pada nozzle dengan dan tanpa spiral pada ujung nozzle.

Aliran air melalui sebuah nozzle akan mengalami penurunan tekanan statis dan peningkatan kecepatan aliran. Pola sebaran aliran fluida setelah melewati nozzle akan dipengaruhi oleh beberapa faktor antara lain : geometri nozzle (sudut tip nozzle $\alpha$, pola spiral), tekanan dan kapasitas aliran.

Atomisasi adalah proses disintegrasi cairan menjadi droplet-droplet kecil pada udara yang bersifat gas. Penggunaan proses penyemprotan pada kehidupan manusia antara lain : penyemprotan hama dan serangga pada bidang pertanian, penyemprotan bahan bakar ke ruang silinder pada bidang motor pembakaran dalam, pada industri untuk printing, cetak, pengecatan, pencucian dan pengontrol debu.

Atomizers / sprayers adalah alat yang digunakan untuk mempercepat aliran fluida yang membentuk lapisan film atau jet yang terpecah dalam filamen dan droplet untuk menghasilkan proses penyemprotan (Papanastasion,1986).

Berbagai variasi simulasi numerik untuk memprediksi aliran semprotan terus dikembangkan. Kini simulasi numerik dipakai dan sebagai prediksi hasil penelitian eksperimental. Persamaanpersamaan fundamental yang mendasari simulasi numerik ini antara lain : (1) Persamaan Konservasi Massa, Momentum dan Energi. (2) k - $\varepsilon$ Persamaan transport untuk energi kinetik turbulen dan dissipasinya. (3) Perubahan momentum antara gas dan droplet (4) Persamaan tingkat keadaan gas ideal. Semua persamaan diselesaikan secara serentak membentuk permasalahan inisialisasi injeksi transien sampai keadaan steady tercapai (O. Rourke, 1981)

Sebuah semprotan terdiri dari droplet dengan ukuran berbeda-beda dan dengan karakteristiknya diperoleh dari hasil eksperimen yang ada. Sampai saat ini belum ada teori yang secara pasti dapat memprediksi distribusi ukuran droplet secara akurat dalam proses penyemprotan. Prediksi yang memungkinkan didasarkan atas hubungan empiris atau idealisasi kasus sederhana. Rayleigh (1978) menganalisa sebuah inviscid jet pada kecepatan rendah yang menghasilkan diameter droplet mendekati 2 kali diameter orifice jet. Kriteria yang paling banyak digunakan untuk semprotan aktual ditemukan oleh Ohnesorge yang didasarkan data eksperimental dan analisa dimensi.

Spray nozzles didesain pada kondisi yang berbeda-beda maka terdapat beberapa pola semprotan yang ada. Pola semprotan ini terbentuk terutama oleh geometri nozzle. Macam-macam model semprotan yang dihasilkan oleh berbagai jenis nozzle dapat dilihat pada gambar 1 .

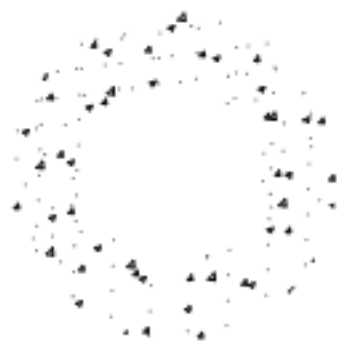

HOLLOW CONE

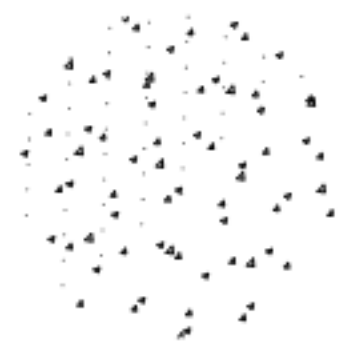

FULL CONE
SOLID STREAM

Gambar 1. Pola semprotan pada berbagai macam nozzle (Spraying System Co.)

Fluida yang mempunyai viskositas yang lebih tinggi akan menyebabkan sudut semprotan lebih kecil dan fluida dengan tegangan permukaan lebih rendah dari air akan menghasilkan sudut 
semprotan relatif lebih lebar dari air.

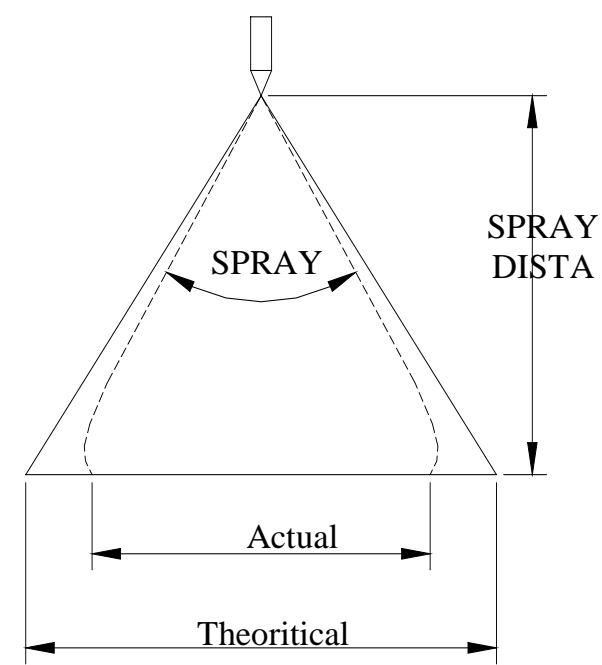

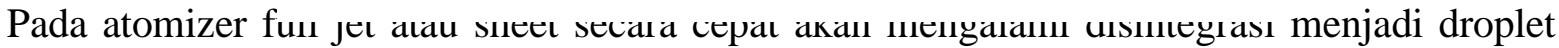
yang bertujuan menjaga arah gerakan dari jet atau cone. Pengaruh gesekan udara pada droplet akan membentuk semprotan di luar yang secara cepat kehilangan momentumnya dan membentuk awan yang teratomisasi sempurna.

Penetrasi dari sebuah semprotan didefinisikan sebagai jarak maksimum yang dicapai ketika fluida diinjeksikan ke udara diam. Penetrasi ini dipengaruhi oleh besaran relatif dari dua gaya yang berlawanan yaitu : (1) Energi kinetik dari fluida (2) Gesekan aerodinamik dari gas sekeliling. Kecepatan fluida yang tinggi akan menghasilkan energi kinetik fluida yang tinggi juga tetapi proses atomisasi dari luas permukaan akan meningkat, energi kinetik fluida yang terbentuk akan terdissipasi oleh gesekan dari gas sekeliling. Droplet yang telah berkurang energi kinetiknya maka lintasan partikelnya hanya dipengaruhi oleh gravitasi dan gerakan gas di sekelilingnya.

Aliran air melalui sebuah nozzle akan mengalami penurunan tekanan statis dan peningkatan kecepatan aliran. Pola sebaran aliran fluida setelah melewati nozzle akan dipengaruhi oleh beberapa faktor antara lain : geometri nozzle (sudut tip nozzle $\alpha$, pola spiral), tekanan dan kapasitas aliran.

Dalam penelitian ini dibahas berapa besar pengaruh tekanan dan kapasitas, sudut tip nozzle terhadap karakteristik nozzle (sudut dan panjang semprotan) dan bagaimana pengaruh penambahan spiral pada ujung nozzle (perbandingan dengan nozzle tanpa spiral).

\section{METODE}

Penyelesaian masalah teknik banyak dilakukan berbagai macam metode baik secara eksperimental maupun simulasi numerik. Ansys merupakan salah satu perangkat lunak yang banyak digunakan untuk menyelesaikan masalah teknik. Ansys menggunakan metode elemen hingga untuk menyelesaikan permasalahan yang ada. Adapun tujuan penggunaannya antara lain :

- Memindahkan model CAD dari model suatu produk atau system untuk dianalisa.

- Menjalankan proses operasi pada kondisi atau beban yang lebih variatif.

- Mempelajari bagaimana respon fisik seperti tegangan, regangan, distribusi temperatur, tekanan, aliran fluida dan medan elektromagnetik.

- Digunakan sebagai prediksi awal desain sebelum eksperimen sesungguhnya dilakukan.

- Menguji model pada kondisi yang diinginkan atau dalam kondisi eksperimen sesungguhnya masih belum dapat dilakukan.

Ada 10 jenis nozzle yang dimodelkan disini, yang terbagi atas : 5 model nozzle dengan spiral dan 5 model tanpa spiral. Klasifikasi model ini didasarkan atas variasi sudut tip nozzle yaitu $128^{0}, 130^{\circ}, 132^{\circ}, 134^{\circ}, 136^{\circ}$. Masing masing model dengan akan disimulasikan dengan kondisi pembebanan sebagai berikut : 
Kondisi pembebanan diatas didasarkan pada brosur spiral jet type HHSJ 40,120 serta eksperimen yang dilakukan Hernoko (2001). Jumlah total seluruh pemodelan berdasarkan atas sudut tip nozzle, dengan atau tanpa spiral, 3 kondisi pembebanan adalah $2 \times 5 \times 3=30$ macam.

Secara garis besar pemodelan ini terbagi menjadi dua kelompok yaitu model spiral nozzle dan tanpa spiral. Pada pemodelan spiral nozzle, lebih dulu pola spiral dibuat dengan bantuan Solid Edge karena Ansys tidak memuat pemodelan spiral. Pola spiral yang sudah ada kemudian di export ke dalam bentuk iges, yang selanjutnya dapat di import lewat Ansys. Adapun geometri pemodelan dapat dilihat sebagai berikut :

$\begin{array}{lll}\text { Diameter dalam nozzle } & : & 0.0056 \mathrm{~m} \\ \text { Diameter orifice } & : & 0.0032 \mathrm{~m} \\ \text { Diameter ruang semprotan (D) } & : & 0.26 \mathrm{~m} \\ \text { Panjang ruang semprotan (L) } & : & 0.3 \mathrm{~m}\end{array}$

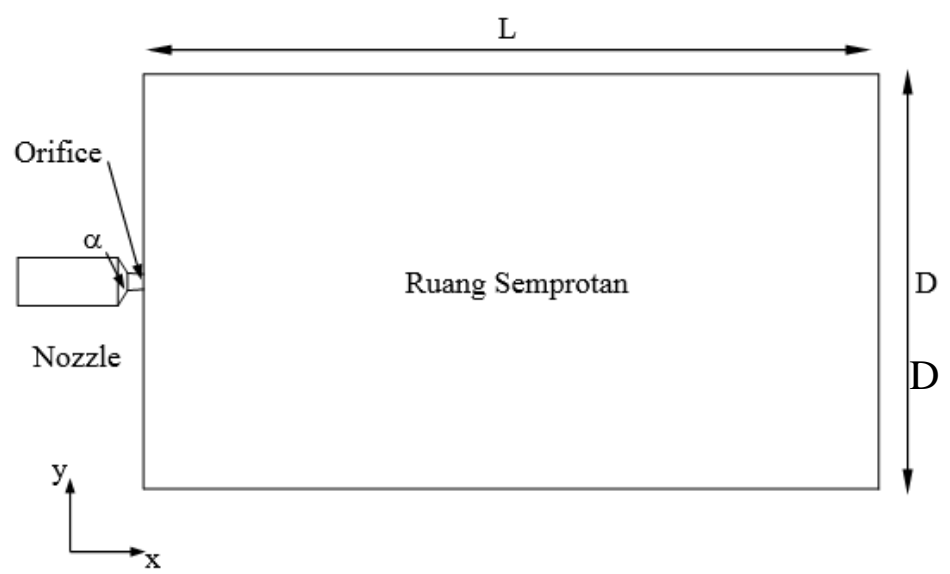

Gambar 3. Geometri Pemodelan Nozzle dan Ruang Semprot Tampak Samping

Penentuan geometri ruang semprotan didasarkan pada percobaan dan keterbatasan perangkat lunak. Hal ini disebabkan bila dimensi ruang semprotan terlalu besar akan mengakibatkan jumlah elemen yang harus dibuat menjadi semakin besar. Ini menyulitkan untuk melihat visualisasi aliran dan kontur dalam ruang semprotan, karena Ansys akan membutuhkan memori yang sangat besar untuk memvisualisasikan hasil iterasi dalam jumlah besar dalam bentuk potongan.

Air yang digunakan disini mempunyai properti yang akan dipakai sebagai variabel perhitungan iterasinya oleh Ansys antara lain : $\mu=0.001 \mathrm{Ns} / \mathrm{m}^{2}, \rho=999 \mathrm{~kg} / \mathrm{m}^{3}$

Kondisi batas dilakukan dengan memberikan batasan pada daerah dimana untuk setiap dinding akan diberi nilai untuk komponen kecepatan arah $\mathrm{x}, \mathrm{y}$ dan $\mathrm{z}$ sama dengan nol, sehingga nantinya tidak ada aliran yang menembus batasan ini (dianggap sebagai batas padat). Pemberian beban dilakukan pada daerah inlet nozzle berupa kecepatan dan tekanan. Kecepatannya bersatuan $\mathrm{m} / \mathrm{s}$ sedangkan tekanannya bersatuan Pascal $\left(\mathrm{N} / \mathrm{m}^{2}\right)$. Untuk lebih jelasnya pemberian beban dapat ditabelkan sebagai berikut : 
Tabel 1. Pemberian beban vektor kecepatan dan tekanan

\begin{tabular}{|c|c|c|c|}
\hline $\begin{array}{c}\text { Sudut Tip Nozzle } \\
\text { Dengan dan tanpa spiral }\end{array}$ & $\begin{array}{l}\text { Debit } \\
(1 / \mathrm{min})\end{array}$ & $\begin{array}{c}\text { Vektor Kecepatan }(\mathbf{m} / \mathbf{s}) \\
\text { arah z }\end{array}$ & $\begin{array}{c}\text { Tekanan } \\
\left(\mathbf{N} / \mathbf{m}^{2}\right)\end{array}$ \\
\hline \multirow{3}{*}{$128^{\circ}$} & 22 & -3.58 & $1.5 \mathrm{E}+05$ \\
\hline & 32 & -5.61 & $3.0 \mathrm{E}+05$ \\
\hline & 48 & -8.41 & $7.0 \mathrm{E}+05$ \\
\hline \multirow{3}{*}{$130^{\circ}$} & 22 & -3.58 & $1.5 \mathrm{E}+05$ \\
\hline & 32 & -5.61 & $3.0 \mathrm{E}+05$ \\
\hline & 48 & -8.41 & $7.0 \mathrm{E}+05$ \\
\hline \multirow{3}{*}{$132^{\circ}$} & 22 & -3.58 & $1.5 \mathrm{E}+05$ \\
\hline & 32 & -5.61 & $3.0 \mathrm{E}+05$ \\
\hline & 48 & -8.41 & $7.0 \mathrm{E}+05$ \\
\hline \multirow{3}{*}{$134^{\circ}$} & 22 & -3.58 & $1.5 \mathrm{E}+05$ \\
\hline & 32 & -5.61 & $3.0 \mathrm{E}+05$ \\
\hline & 48 & -8.41 & $7.0 \mathrm{E}+05$ \\
\hline \multirow{3}{*}{$136^{\circ}$} & 22 & -3.58 & $1.5 \mathrm{E}+05$ \\
\hline & 32 & -5.61 & $3.0 \mathrm{E}+05$ \\
\hline & 48 & -8.41 & $7.0 \mathrm{E}+05$ \\
\hline
\end{tabular}

Data analisa diperoleh dari hasil simulasi pemodelan. Kondisi sistem instalasi dan beban diterapkan dalam pemodelan dengan beberapa kriteria dan asumsi sebagai berikut :

- Proses atomisasi air dalam kondisi steady.

- Air adalah fluida incompressible.

- Aliran turbulen.

- Viskositas dan densitas dianggap tetap.

- Tekanan kerja dan debit didasarkan pada percobaaan sebelumnya dan brosur spiral jet nozzle.

- Pemodelan turbulen menggunakan $\mathrm{k}-\varepsilon$. 


\section{HASIL DAN PEMBAHASAN}

Pengambilan data hasil pemodelan dilakukan setelah serangkaian proses membuat model, penentuan beban sampai dengan iterasinya dari masing - masing model. Data - data yang diambil dalam pemodelan ini antara lain adalah : kecepatan maksimum hasil pemodelan $\left(\mathrm{V}_{\max }\right)$, sudut semprotan $(\beta)$. Hasil simulasi numerik ini ditampilkan dalam bentuk vektor dan kontur kecepatan dan tekanan dapat dilihat pada lampiran.

Tabel 2. Data hasil simulasi pemodelan numerik

\begin{tabular}{|c|c|c|c|c|c|}
\hline $\begin{array}{l}\text { Jenis } \\
\text { Nozzle }\end{array}$ & $\begin{array}{c}\text { Sudut Nozzle } \\
\beta\end{array}$ & $\begin{array}{c}\text { Tekanan } \\
\text { (bar) }\end{array}$ & $\begin{array}{l}\text { Debit } \\
\text { (L/min) }\end{array}$ & $\begin{array}{r}\text { Vmax } \\
(\mathrm{m} / \mathrm{s})\end{array}$ & $\begin{array}{c}\text { Sudut Semprotan } \\
\beta\end{array}$ \\
\hline \multirow{15}{*}{ 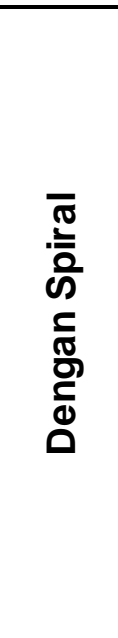 } & \multirow{3}{*}{128} & 1.5 & 22 & 16.198 & 110 \\
\hline & & 3 & 32 & 24.165 & 115 \\
\hline & & 7 & 48 & 37.82 & 119 \\
\hline & \multirow{3}{*}{130} & 1.5 & 22 & 16.203 & 114 \\
\hline & & 3 & 32 & 24.255 & 121 \\
\hline & & 7 & 48 & 38.057 & 124 \\
\hline & \multirow{3}{*}{132} & 1.5 & 22 & 16.245 & 119 \\
\hline & & 3 & 32 & 24.288 & 125 \\
\hline & & 7 & 48 & 38.164 & 131 \\
\hline & \multirow{3}{*}{134} & 1.5 & 22 & 16.313 & 123 \\
\hline & & 3 & 32 & 24.317 & 130 \\
\hline & & 7 & 48 & 38.259 & 135 \\
\hline & \multirow{3}{*}{136} & 1.5 & 22 & 16.327 & 129 \\
\hline & & 3 & 32 & 24.344 & 137 \\
\hline & & 7 & 48 & 38.43 & 142 \\
\hline \multirow{15}{*}{ 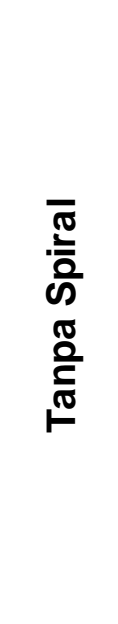 } & \multirow{3}{*}{128} & 1.5 & 22 & 16.413 & 49 \\
\hline & & 3 & 32 & 24.430 & 58 \\
\hline & & 7 & 48 & 39.330 & 62 \\
\hline & \multirow{3}{*}{130} & 1.5 & 22 & 16.367 & 50 \\
\hline & & 3 & 32 & 24.384 & 61 \\
\hline & & 7 & 48 & 39.090 & 63 \\
\hline & \multirow{3}{*}{132} & 1.5 & 22 & 16.353 & 54 \\
\hline & & 3 & 32 & 24.348 & 65 \\
\hline & & 7 & 48 & 38.980 & 68 \\
\hline & \multirow{3}{*}{134} & 1.5 & 22 & 16.319 & 56 \\
\hline & & 3 & 32 & 24.319 & 67 \\
\hline & & 7 & 48 & 38.660 & 71 \\
\hline & \multirow{3}{*}{136} & 1.5 & 22 & 16.290 & 59 \\
\hline & & 3 & 32 & 24.284 & 72 \\
\hline & & 7 & 48 & 38.230 & 75 \\
\hline
\end{tabular}

\section{Analisis Grafik}

Penentuan sudut semprotan diperoleh dengan mengukur gambar simulasi aliran pada exit orifice sesuai dengan distribusi vektor komponen kecepatannya. Adapun penentuan panjang semprotan (spray distance) tidak dapat ditentukan secara eksak karena keterbatasan pemodelan. Pemodelan ruang semprotan yang terlalu besar disamping memakan waktu yang lama untuk iterasinya juga semua nodal yang tidak diberi kondisi batas $\mathrm{V}=0$ akan diberi nilai walaupun sangat kecil. Ini menyulitkan untuk menentukan daerah dimana komponen kecepatan akan menjadi nol. Panjang penetrasi ini dapat didekati dengan membandingkan kecepatan maksimum $\left(\mathrm{V}_{\max }\right)$ masingmasing pemodelan.

Secara umum penambahan tekanan dan debit akan menambah sudut semprotan dan panjang penetrasinya. Panjang penetrasi yang dalam hal ini dianalogikan dengan kecepatan maksimum fluida meninggalkan exit orifice akan turun. Hal ini dapat dijelaskan bahwa untuk pembebanan 
tekanan dan debit yang sama dengan variasi sudut tip nozzle $\alpha$ yang semakin besar pada nozzle tanpa spiral akan menghasilkan sudut semprotan yang besar tetapi kecepatan maksimumnya akan turun karena sudut tip nozzle yang semakin besar akan menghasilkan sudut semprotan yang besar pula sehingga luasan frontal ke arah aksial menjadi lebih besar. Luasan frontal aksial yang besar akan menghambat aliran sehingga menyebabkan kecepatan keluar exit orifice menjadi mengecil.

Penambahan sudut tip nozzle $\alpha$, tekanan dan debitnya juga akan menyebabkan naiknya sudut semprotan $\beta$ dan panjang peneterasinya, ini berbeda dengan nozzle tanpa spiral yang panjang penetrasinya turun. Hal tersebut dapat dijelaskan bahwa pada spiral nozzle aliran yang keluar akan membentuk luasan frontal yang lebih kecil (pola hollow cone) dibanding dengan nozzle tanpa spiral (pola full cone). Luasan frontal yang lebih kecil ini akan mengurangi hambatan ke arah aksial sehingga untuk penambahan sudut tip $\alpha$, debit dan tekanan akan menyebabkan naiknya sudut semprotan $\beta$ dan panjang penetrasinya.

Hasil pemodelan ini akan dibandingkan dengan hasil eksperimental yang dilakukan oleh Hernoko (2001). Beberapa hal identik dengan hasil eksperimen sebelumnya akan tetapi skala harga pada pemodelan menjadi lebih besar akibat tidak semua faktor pada kondisi real dapat didekati sama persis pada pemodelan numerik. Perbandingan hasil eksperimental yang dilakukan oleh Hernoko (2001) dengan spiraljet nozzle tipe HHSJ 40,120 sudut tip nozzle $132^{\circ}$ diperoleh sebagai berikut :

Tabel 3. Perbandingan hasil eksperimental dan pemodelan spiral nozzle

Sudut tip Nozzle $\alpha=132^{\circ}$

\begin{tabular}{|c|c|c|c|c|c|c|}
\hline $\begin{array}{c}\mathbf{P} \\
\text { (bar) }\end{array}$ & $\begin{array}{c}\mathbf{Q}_{\text {model }} \\
(\mathbf{L} / \mathbf{m i n})\end{array}$ & $\begin{array}{c}\mathbf{Q}_{\text {exp }} \\
(\mathbf{L} / \mathbf{m i n})\end{array}$ & $\begin{array}{c}\mathbf{V m a x}_{\text {model }} \\
(\mathbf{m} / \mathbf{s})\end{array}$ & $\begin{array}{c}\mathbf{V m a x}_{\exp } \\
(\mathbf{m} / \mathbf{s})\end{array}$ & $\boldsymbol{\beta}_{\text {model }}$ & $\boldsymbol{\beta}_{\exp }$ \\
\hline 1.5 & 22 & 12 & 16.245 & 8.14 & 119 & 116 \\
3 & 32 & 16.67 & 24.288 & 11.28 & 125 & 120 \\
6.5 & 48 & 27 & 38.164 & 18.46 & 131 & 127 \\
\hline
\end{tabular}

Pada nozzle tanpa spiral menunjukkan tren yang sama baik penambahan sudut tip nozzle atau debit dan tekanan akan mempengaruhi kenaikan kecepatan maksimum $\mathrm{V}_{\max }$ dan sudut semprotannya. Bila dibandingkan dengan spiral nozzle maka $\mathrm{V}_{\max }$ yang dicapai nozzle tanpa spiral relatif lebih besar ini disebabkan faktor penghalang pada exit orificenya lebih kecil dari spiral nozzle, sehingga aliran akan lebih cepat meninggalkan exit orifice nozzle tanpa spiral. Spiral nozzle memiliki sudut semprotan yang lebih besar dari nozzle tanpa spiral. Hal ini disebabkan pada spiral nozzle aliran yang keluar exit orifice-nya akan dituntun oleh pola spiral sehingga sebaran aliran dapat lebih lebar dari nozzle tanpa spiral serta luasan frontal arah aksial lebih kecil dari nozzle tanpa spiral. 
$\mathrm{P}=1.5 \mathrm{bar}$

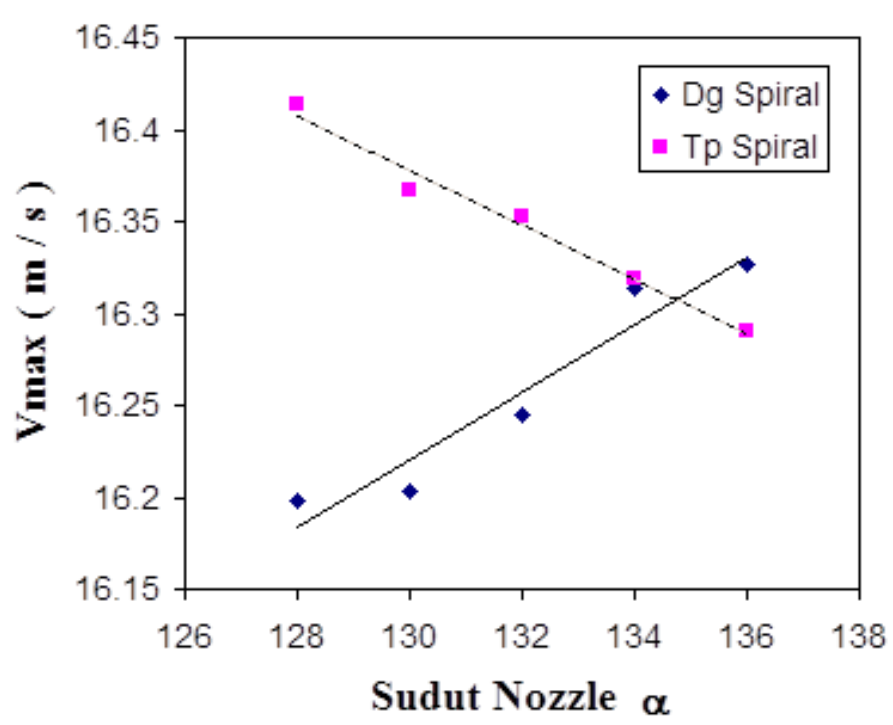

$\mathrm{P}=\mathbf{3}$ bar

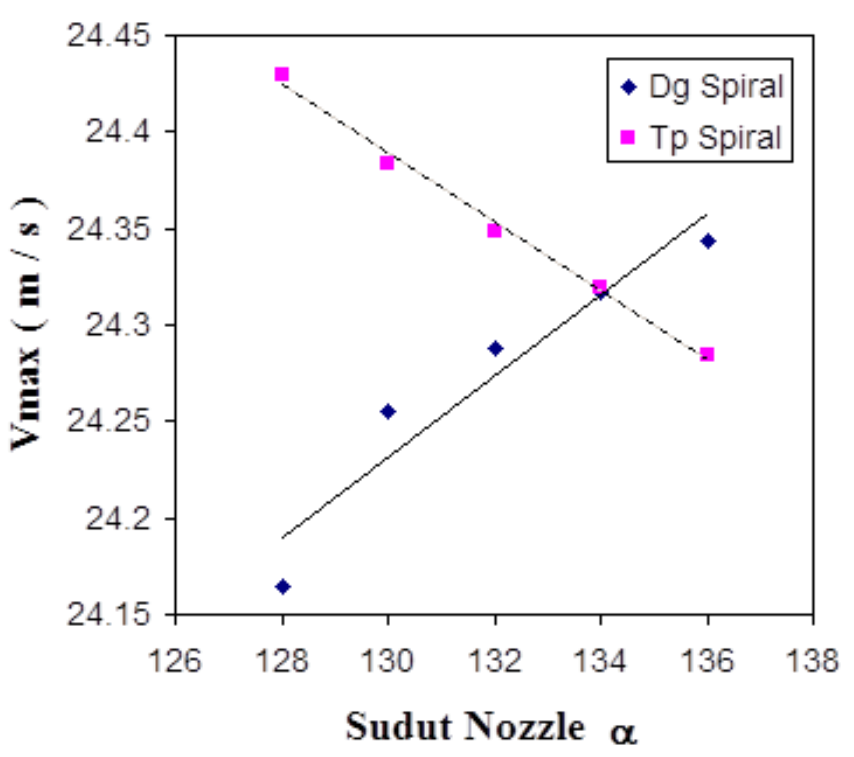

Gambar 5. $\mathrm{V}_{\max }-$ Sudut Nozzle $\alpha ; \mathrm{P}=3$ bar

Gambar 4. $\mathrm{V}_{\max }-$ Sudut Nozzle $\alpha ; \mathrm{P}=1.5$ bar

$P=7$ bar

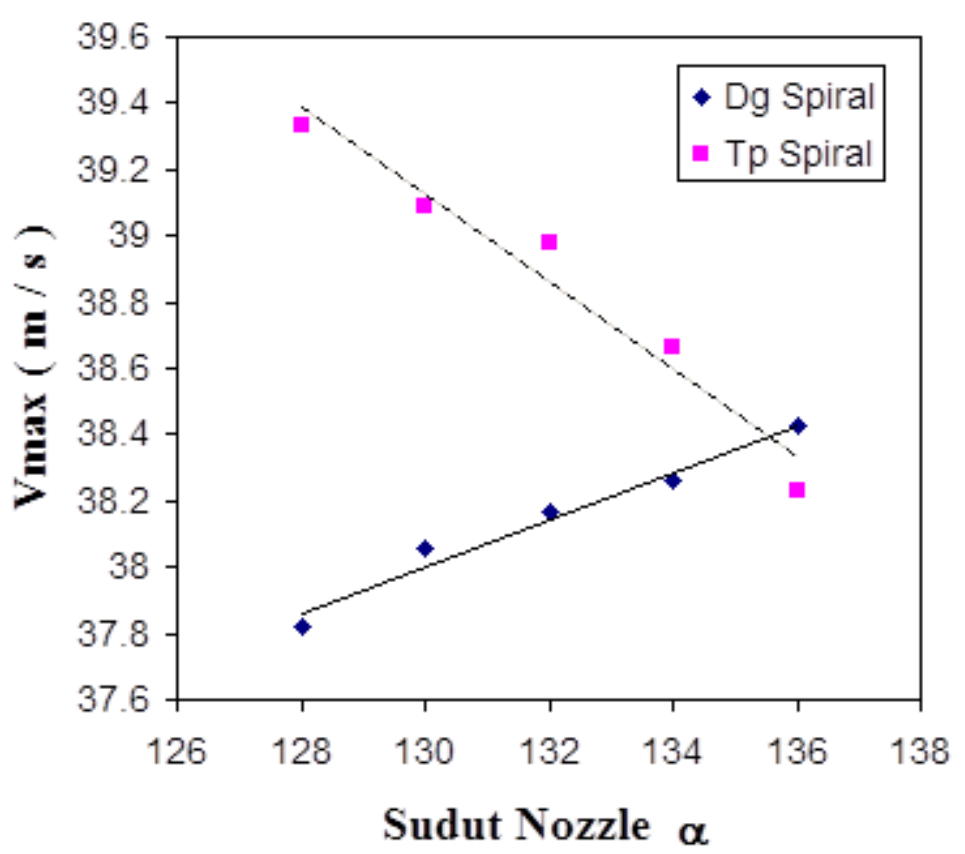

Gambar 6. $\mathrm{V}_{\max }-$ Sudut Nozzle $\alpha ; \mathrm{P}=7$ bar 
$\mathrm{P}=1.5 \mathrm{bar}$

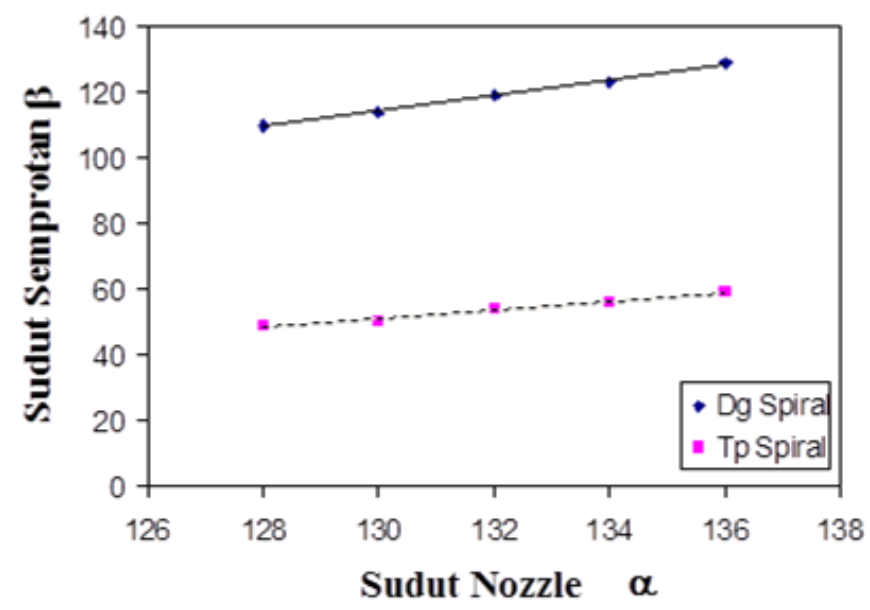

Gambar 7.Sudut Nozzle $\alpha$ - Sudut Semprotan $\beta ; \mathrm{P}=1.5$ bar
$\mathbf{P}=\mathbf{3}$ bar

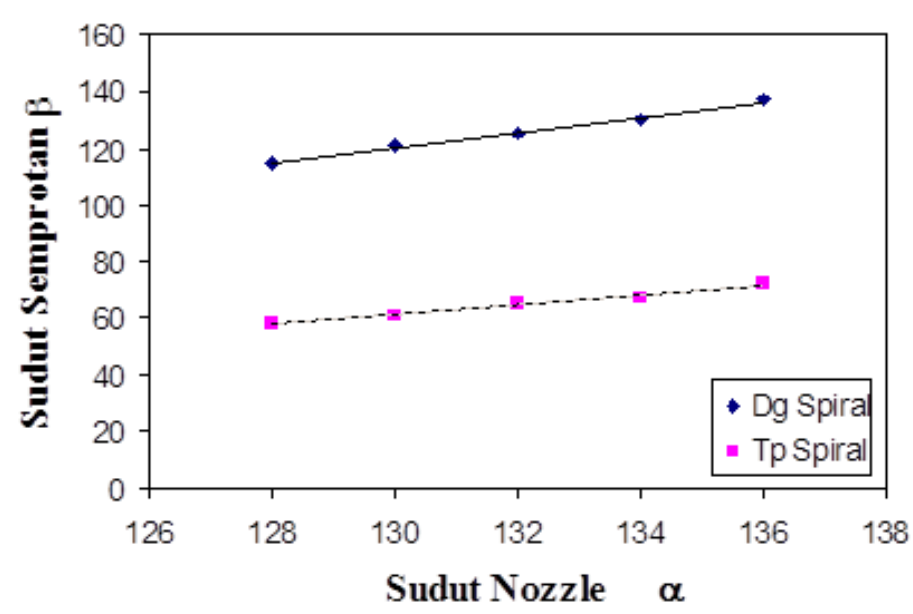

Gambar 8.Sudut Nozzle $\alpha$ - Sudut Semprotan $\beta ; \mathrm{P}=3$ bar $\mathbf{P}=7$ bar

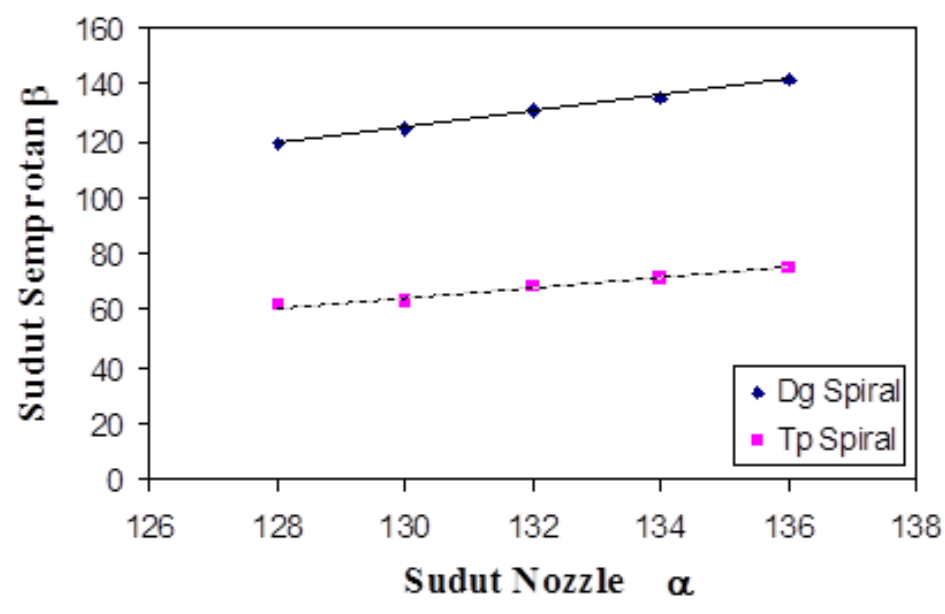

Gambar 9. Sudut Nozzle $\alpha$ - Sudut Semprotan $\beta ; \mathrm{P}=7$ bar

\section{Pemilihan Semprotan Nozzle Optimal}

Pemilihan suatu semprotan yang optimal ditentukan oleh dua kriteria yaitu :

1. Memiliki panjang semprotan (spray distance) yang besar (identik dengan $\mathrm{V}_{\max }$ ). Kriteria ini dipilih untuk kondisi bentuk ruang semprotan yang memanjang.

2. Memiliki sudut semprotan $\beta$ yang besar. Kriteria ini dipilih untuk kondisi ruang semprotan yang lebar.

Berdasarkan grafik 7-9, dapat dilihat bahwa jangkauan pemodelan belum mencapai titik optimal. Dua kriteria diatas dapat diambil titik maksimalnya yaitu spiral nozzle dengan sudut tip $136^{\circ}$ dengan tekanan 7 bar dan debit $48 \mathrm{~L} / \mathrm{min}$. Pemilihan secara aktual harus dilihat kondisi sistem, baik tekanan maupun bentuk ruang semprotannya. Apabila faktor yang dilihat hanya tekanan dan debit yang besar saja tidak akan diperoleh hasil optimal, karena nozzle akan cepat aus serta gas hasil pembakaran yang seharusnya keluar akan berbalik bersama residu hasil pembakaran sehingga akan menyebabkan kerusakan pada sistem yang lebih besar. Bila tekanan dan debit terlalu kecil maka akan mengakibatkan penyumbatan (clogging) pada nozzle dan atomisasi tidak bisa menghasilkan droplet yang memadai, serta adanya residu yang terbuang bersama gas hasil pembakaran. Visualisasi aliran pada nozzle dapat dilihat pada gambar 10. 


\section{PENUTUP \\ Simpulan}

Kesimpulan akhir dari hasil pemodelan numerik ini adalah :

1. Nozzle tanpa spiral mempunyai karakteristik yaitu kenaikan sudut semprotan $(\beta)$ yang dipengaruhi oleh sudut tip nozzle $(\alpha)$ tekanan dan debit akan menghasilkan panjang penetrasi / kecepatan maksimumnya $\left(\mathrm{V}_{\max }\right)$ menurun.

2. Spiral nozzle mempunyai karakteristik yang berbeda, yaitu kenaikan sudut semprotan ( $\beta$ ) yang dipengaruhi oleh sudut tip nozzle $(\alpha)$ tekanan dan debit akan menghasilkan panjang penetrasi / kecepatan maksimumnya $\left(\mathrm{V}_{\max }\right)$ juga naik.

3. Pola spiral pada exit orifice berfungsi untuk menuntun aliran keluar sehingga membentuk pola lapisan-lapisan fluida yang melingkar, juga berfungsi untuk memperlebar sudut semprotan serta mencegah terjadinya penyumbatan (clogging) karena proses penangkapan debu tidak langsung berhadapan pada exit orifice.

4. Nozzle terbaik untuk kriteria maksimal adalah spiral nozzle dengan sudut tip $\alpha=136^{\circ}$ debit 48 L / min dan tekanan 7 bar.

5. Besar nilai pada hasil pemodelan cenderung lebih besar dari hasil eksperimental dikarenakan tidak semua pemodelan eksperimental dapat dicakup oleh pemodelan numerik, disamping banyak idealisasi pada pemodelan numerik ini. Namun kecenderungan suatu model terhadap hasilnya memiliki kesamaan-kesamaan.

\section{DAFTAR PUSTAKA}

[1] Fox, Robert. W and McDonald, Alan.T, Introduction to Fluid Mechanics, $3^{\text {rd }}$ edition, John Wiley \& Sons Inc, New York, 1985

[2] Papanastasion, Tasos. C, Applied Fluid Mechanics, Prentice-Hall International Inc., 1986

[3] Reddy, J.N., An Introduction to the Finite Element Method, McGraw Hill Inc., 1984

[4] Anderson, John D. JR, Computational Fluid Dynamics, McGraw Hill Inc., 1995

[5] Brochure Spraying System Co., Hollow Cone and Full Cone Spray Nozzles

[6] Okamoto, Tatsuyuki, Studies on the Behavior Droplets and the Air Flow in a Hollow Cone Spray, Journal oh Fluid Engineering pp 586-592., 1998

[7] Ansys Inc., CFD Flotran Analysis Guide, 1998

[8] Ansys Inc., Basic Analysis Procedures Guide, 1998

[9] Ansys Inc., Theory Reference Guide, 1998

[10] Chapra, Steven C. and Canale, Raymond P., Numerical Methods For Engineers, McGrawHill Book Company., 1985

[11] Shaw, C.T., Using Computational Fluid Dynamics, Prentice-Hall International Inc., 1992

[12] Hernoko, Venu, Tugas Akhir : Studi Eksperimental Perbandingan Karakteristik Spiraljet Nozzle dengan Fulljet Nozzle. , 2001 


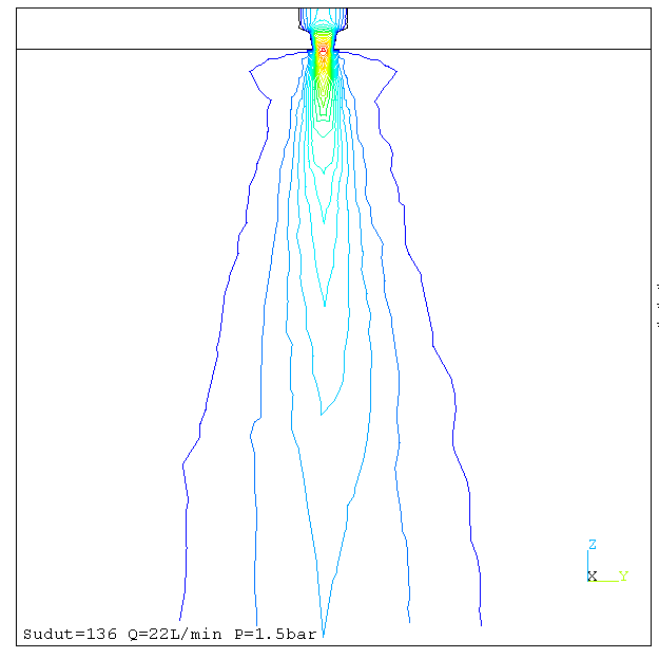

a. Sudut $136^{\circ} ; \mathrm{P}=1.5$ bar Tanpa Spiral

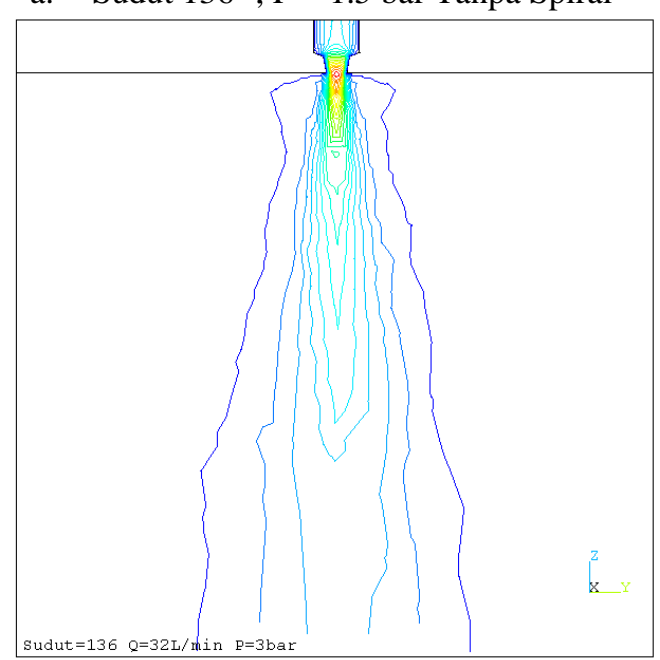

e. Sudut $136^{\circ} ; \mathrm{P}=3$ bar Tanpa Spiral
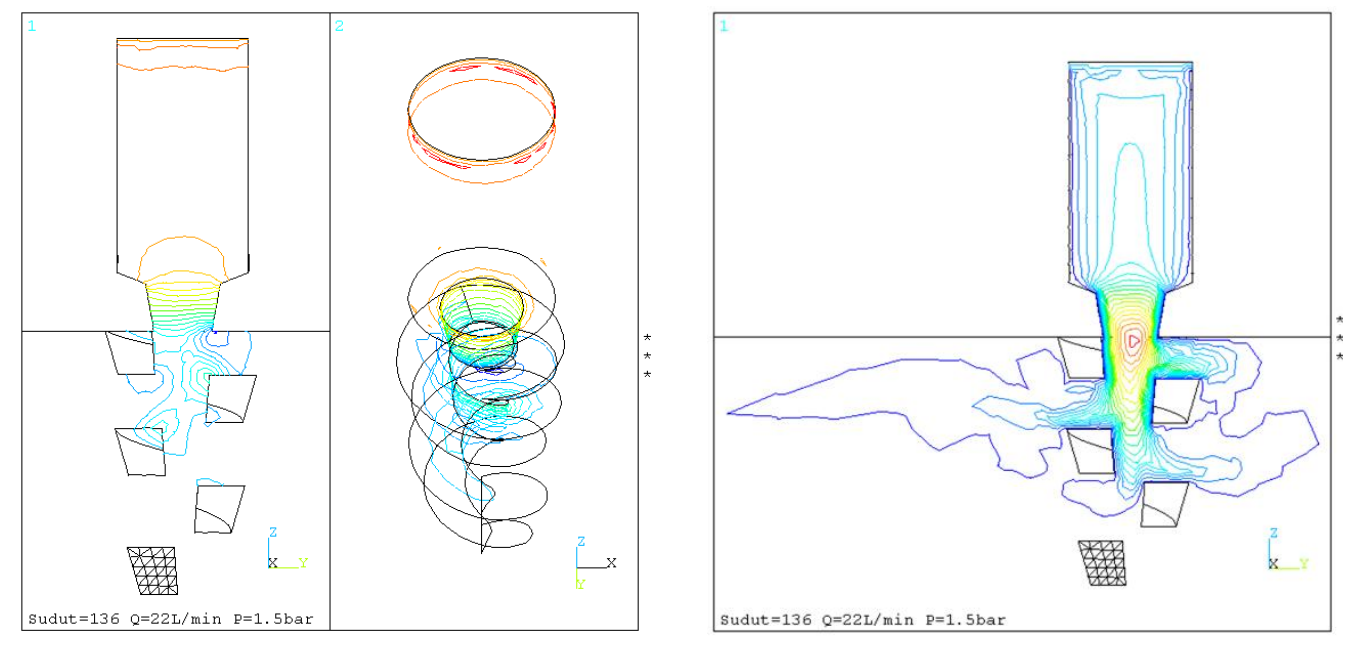

d. Sudut $136^{\circ} ; \mathrm{P}=1.5$ bar dengan Spiral
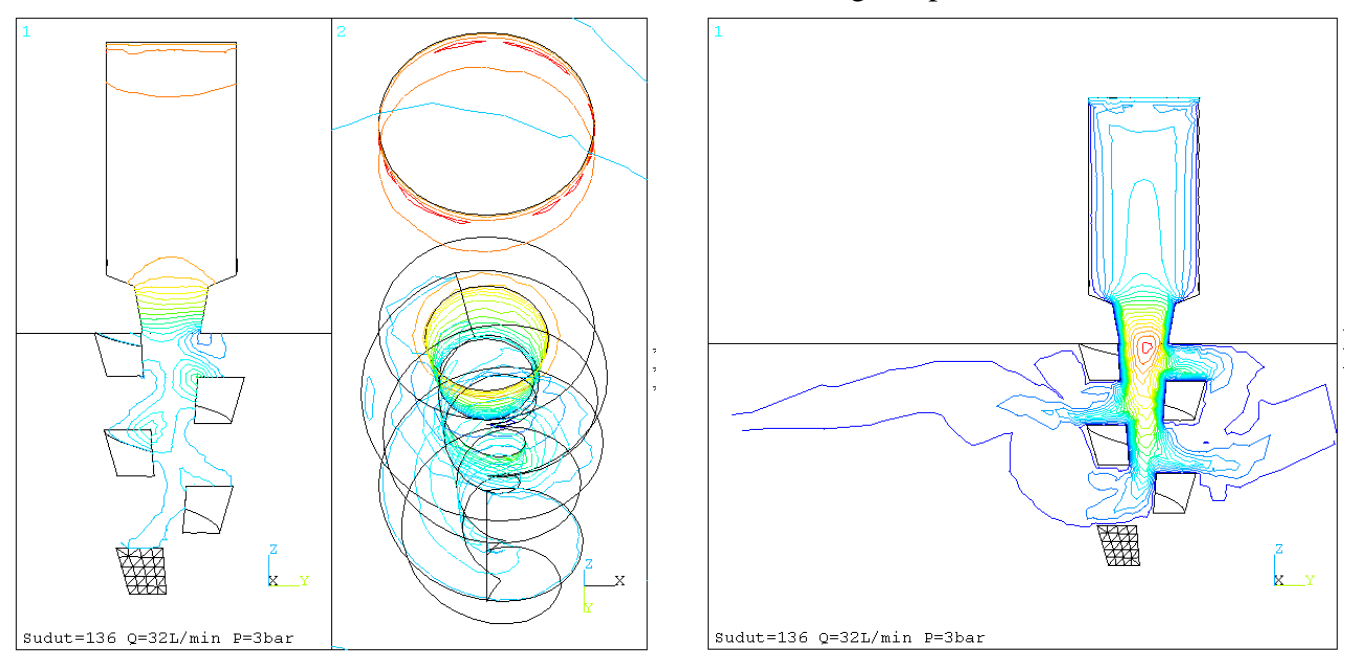

f. Sudut $136^{\circ} ; \mathrm{P}=3$ bar dengan Spiral 


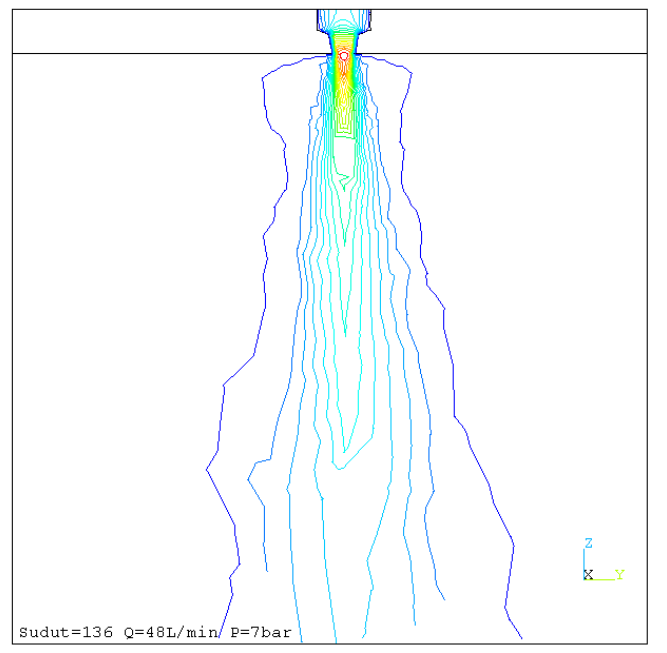

g. Sudut $136^{\circ} ; \mathrm{P}=7$ bar Tanpa Spiral

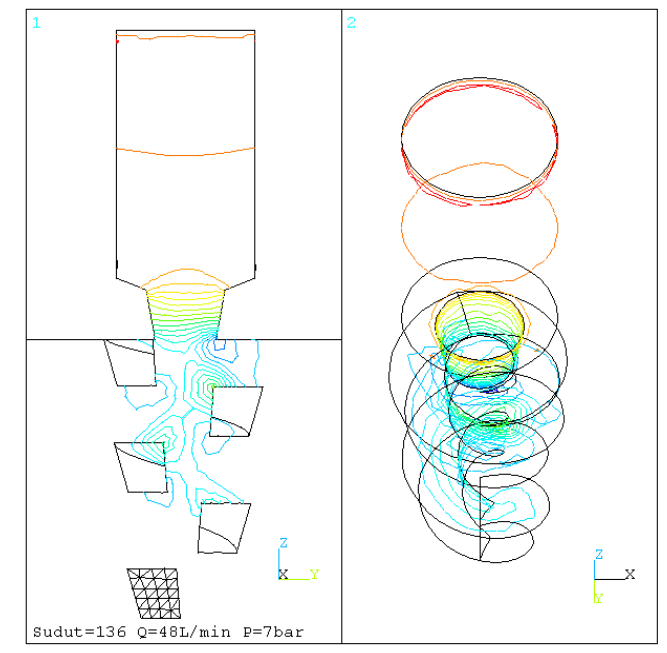

h. Sudut $136^{\circ} ; \mathrm{P}=7$ bar dengan Spiral

Gambar 10. Kontur Kecepatan Spiral Nozzle dan Tanpa Spiral

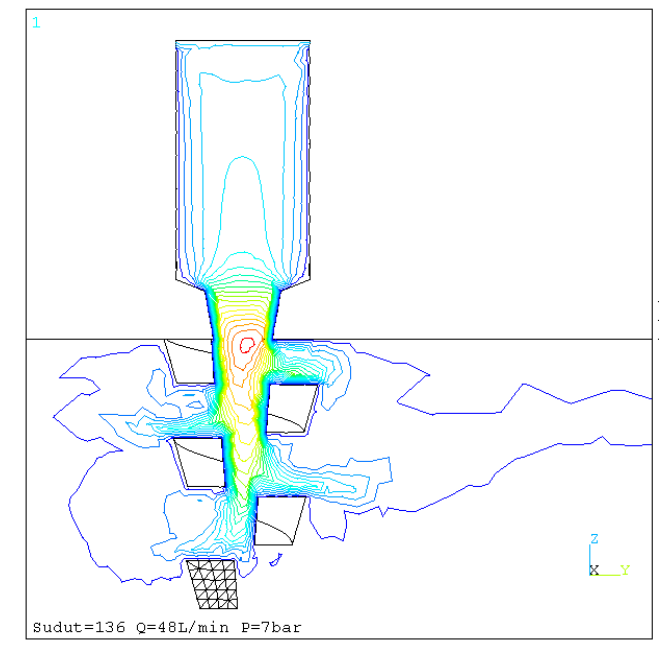

